\title{
HUBUNGAN ANTARA PENGHARGAAN DIRI DAN KEMAMPUAN MENULIS OLEH SISWA TAHUN PERTAMA DI SMAN 1 PEKANBARU
}

\author{
Rizka Desia Asri ${ }^{1}$, Jismulatif ${ }^{2}$ \\ 1) SMA Negeri 1 Pekanbaru, Universitas Riau, \\ 2) Program Pendidikan Bahasa Inggris FKIP, Universitas Riau \\ rizkadesia@gmail.com
}

\begin{abstract}
ABSTRAK: Penelitian ini bertujuan untuk mengetahui hubungan antara penghargaan diri dan kemampuan menulis pada siswa tahun pertama di SMAN 1 Pekanbaru. Penelitian ini merupakan penelitian korelasi yang melibatkan dua variabel. Sampel pada penelitian ini adalah satu kelas yang terdiri dari 36 siswa. Kelas ini dipilih dengan teknik pengambilan acak kelompok. Dalam penelitian ini, kuisioner penghargaan diri dan tes menulis digunakan untuk mengumpulkan data. Data penghargaan diri diperoleh dengan menggunakan serangkaian kuisioner FLSES (Foreign Language Self-Esteem Scale) atau skala ukur penghargaan diri bahasa asing yang di desain oleh Hassan (2001) dan data kemampuan menulis diperoleh dengan memberikan tes menulis. Kedua data tersebut dianalisa dengan menggunakan Pearson Product Moment Correlation. Hasil dari penelitian ini menyatakan bahwa terdapat hubungan yang rendah antara penghargaan diri dan kemampuan menulis siswa pada nilai korelasi 0.312, sedangkan koefisien korelasinya yaitu sebesar $9.7 \%$. Penghargaan diri siswa berada pada tingkat "rata-rata" dan kemampuan menulis siswa berada pada tingkat "baik". Hal ini menunjukkan bahwa penghargaan diri siswa mempengaruhi kemampuan menulisnya. Berdasarkan penemuan ini, barangkali akan lebih baik bagi para siswa untuk memeperhatikan aspek kepribadian seperti penghargaan diri pada proses pembelajaran menulis.
\end{abstract}

Kata kunci: Hubungan, penghargaan diri, Kemampuan menulis. 


\title{
THE CORRELATION BETWEEN SELF-ESTEEM AND WRITING ABILITY OF THE FIRST YEAR STUDENTS OF SMAN 1 PEKANBARU
}

\begin{abstract}
The objective of this research is to determine the correlation between selfesteem and writing ability of the first year students of SMAN 1 Pekanbaru. This is a correlational research that hastwo variables. The sample of this research is one class consisted of 36 students. The class was chosen by using Cluster Random Sampling Technique. Selfesteem questionnaire and writing test were used to collect the data. The self-esteem data were collected by using a set of questionnaire FLSES (Foreign Language Self-Esteem Scale) designed by Hassan (2001). The data of writing ability were taken by administaring test of writing. The collected data were analyzed by using Pearson Product Moment Correlation. The result shows that there is low correlation between students' self-esteem and writing ability with the correlation value 0.312, while the coefficient correlation is as big as $9.7 \%$. The self-esteem of the students is categorized in "average" level and the writing ability is categorized in "good" level. It indicates that the students' self-esteem influences their writing ability. Based on the finding, probably it would be better for the students to pay attantion on personality aspect, such as self-esteem in learning process of writing.
\end{abstract}

Keywords: Correlation, Self-esteem, Writing ability

\section{PENDAHULUAN}

Di Indonesia, bahasa Inggris merupakan mata pelajaran yang harus diajarkan di sekolah sebagaimana dikatakan pada kurikulum pendidikan di Indonesia. Berdasarkan kurikulum 2013 (K13), materi pembelajaran bahasa Inggris ditekankan pada kemampuan bahasa sebagai alat komuniklasi untuk menyampaikan gagasan atau pendapat serta pengetahuan. Para guru harus mengajarkan 4 kemampuan bahasa dalam pengajaran bahasa Inggris, yaitu mendengarkan, membaca, menulis dan berbicara. Salah satu kemampuan bahasa Inggris yang harus dikuasai oleh siswa disamping mendengar, membaca dan berbicara yaitu menulis. Menulis merupakan salah satu kemampuan penting yang harus dipelajari, karena menulis digunakan untuk berkomunikasi. Siswa harus mampu berkomunikasi tidak hanya secara lisan tetapi juga tulisan.

Menulis juga merupakan salah satu kemampuan produktif dimana sesorang menghasilkan bukan menerima. Seperti yang dikemukakan oleh Harmer (2007), kemempuan produktif yaitu kemampuan berbicara dan menulis dimana para siswa harus 
memproduksi atau menhasilkan bahasa sendiri. Semenjak menghasilkan lebih sulit dari pada menerima, kebanyakan siswa beranggapan bahwa menulis sulit untuk dilakukan terutama menulis dalam bahasa asing karena siswa tidak hanya memikirkan apa yang harus mereka tulis tetapi mereka juga harus menyusun gagasan yang akan ditulis dengan tepat dan benar agar mudah dibaca dan dipahami oleh pembaca.

Pada saat seseorang menghasilkan atau memproduksi sesuatu, orang lain akan memperhatikan, memberikan komentar dan penilaian. Komentar dan penilaian yang diberikan bisa berbentuk positif dan negatif. Alhasil, para siswa merasa tidak nyaman ketika menulis dalam bahasa Inggris karena mereka khawatir akan penilaian dan komentar yang diberikan sehinggan mereka berfikiran bahwa mereka tidak mampu menulis dengan baik dan hal ini mempengaruhi kualitas menulis mereka.

Kualitas dan kemampuan menulis siswa dapat dipengaruhi oleh beberapa faktor, salah satunya adalah faktor kepribadian seperti penghargaan diri. Faktor ini bisa menyebabkan siswa berfikir bahwa mereka tidak bisa menulis dengan baik karena menulis juga merupakan kemampuan yang tidak mudah. Aspek penghargaan diri merupakan bagaiman kita menilai dan mempersepsikan diri kita, hal ini didasarkan pada pendapat dan keyakinan kita terhadap diri kita. Seperti yang dikemukakan oleh Dedmond (2009) didalam Hisken (2011) bahwa penghargaan diri merupakan komplikasi perasaan terhadap diri kita yang menuntun kebiasaan, mempengaruhi sikap serta mendorong motivasi kita. Hal ini merupakan perasaan tentang kemampuan dan penilaian kita terhadap diri yang bisa berupa perasaan baik atau buruk. Jadi, dari teoriteori tersebut kita dapan mengkaitkan penghargaan diri terhadap hasil belajar siswa

Penghargaan diri merupakan aspek kepribadian yang berperan penting dalam proses pembelajara. Seperti yang dikemukakan oleh Brown (2000) bahwa tidak ada aktifitas kognitif dan afektif yang sukses dilakukan tanpa beberapa kadar harga diri, kepercayaan diri, pengetahuan akan diri serta keyakinan terhadap kemampuan diri untuk aktifitas atau sesuatu yang dilakukan. Jadi, dapat ditarik kesimpulan bahwa penghargaan diri dapat mempengaruhi kesuksesan dalam belajar seperti pembelajaran bahasa Inggris di sekolah.

Terdapat beberapa peneliti sebelumnya yang telah melakukan penelitian mengenai penghargaan diri dan hasil yang dicapai pada bahasa Inggris. Pertama yaitu penelitian yang dilakukan oleh Hassan (2001) mengenai hubungan kekhawatiran menulis dan penghargaan diri terhadap kualitas dan kuantitas menulis pada mahasiswa dimana bahasa Inggris merupakan bahasa asing bagi mereka. Penelitian ini dilakukan di Universitas Mansoura, Mesir. Hasil penelitian menunjukkan bahwa terdapat hubungan antara kekhawatiran menulis dan penghargaan diri terhadap kualitas dan kuantitas 
menulis dimana mahasiswa yang memiliki kekahawatiran yang rendah memiliki penghargaan diri yang tinggi ketika menulis dari pada mahasiswa dengan kekhawatiran yang tinggi, sedangkan siswa dengan penghargaan diri yang rendah lebih khawatir ketika menulis dari pada mahasiswa yang memiliki penhargaan diri tinggi. Kemudian penelitian yang dilakukan oleh Satriani (2014), yaitu mengenai hubungan antara penghargaan diri siswa terhadap kemampuan bahasa Inggris. Penelitian ini dilakukan pada mahasiswa S2 pendidikan bahasa Inggris di Bandung dengan membagikan kuisioner dan melakukan tes TOEFL. Hasil dari penelitian menunjukkan bahwa terdapat hubungan yang signifikan pada dua variabel dimana hampir seluruh siswa dengan skor TOEFL yang tinggi memiliki penghargaan diri yang baik ketika mengatasi tes kemampuan bahasa Inggris. Hal ini dapat ditegaskan bahwa mereka tidak mudah menyerah ketika mengalami kesulitan.

Berdasarkan latar belakang dan kajian literatur diatas dapat dirumuskan masalah yaitu "apakah terdapat hubungan diantara penghargaan diri dan kemampuan menulis pada siswa tahun pertama SMAN 1 Pekanbaru?". Dari perumusan masalah tersubut maka tujuan dari penelitian ini yaitu untuk menentukan apakah ada hubungan antara penghargaan diri dan kemampuan menulis pada siswa tahun pertama SMAN 1 Pekanbaru.

\section{METODE}

Penelitian ini merupakan penelitian kuantitatif yang menggunakan model expost facto dimana peneliti tidak memberikan percobaan ataupun mempengaruhi pembelajaran dan hasil belajar siswa, tetapi peneliti hanya mengumpulkan data dan melihat hubungan antara dua variabel. Populasi pada penelitian ini yaitu siswa tahun pertama atau kelas X SMAN 1 Pekanbaru tahun ajaran 2018/2019, kemudian sampel yang terpilih pada penelitian ini yaitu kelas X MIA 2 SMAN 1 Pekanbaru. Dalam penelitian ini digunakan 2 instrumen untuk memperoleh data, yaitu kuisioner dan tes menulis. Kuisioner yang digunakan dalam penelitian ini yaitu FLSES (Foreign Language Self-Esteem Scale) atau skala penghargaan diri bahasa asing yang diadaptasi dari Hassan (2001), sedangkan untuk memperoleh data kemampuan siswa dalam menulis, peneliti melakukan tes menulis terhadap siswa dimana para siswa diminta untuk menuliskan salah satu genre teks dalam bahasa Inggris yaitu recount text yang menceritakan tentang pengalaman mereka di masa lalu. Setelah itu, data yang diperoleh di analisis menggunakan korelasi momen produk Pearson pada SPSS 20.0. 


\section{HASIL DAN PEMBAHASAN}

Setelah mengumpulkan hasil menulis siswa, peneliti memberikan hasil tersebut kepada tim penilai. Peneliti menggunakan jasa 3 orang penilai yang merupakan guru bahasa Inggris dan juga memiliki latar belakang dalam dunia pendidikan untuk menilai hasil tulisan siswa. Untuk memastikan keandalan skor dan menghindari subjektivitas dalam penelitian ini, peneliti melakukan tes keandalan menggunakan SPSS 20.0. Hasil dari tes dapat dilihat pada tabel dibawah ini:

Tabel 1. Tes Keandalan

\begin{tabular}{cc}
\hline \multicolumn{2}{c}{ Statistik Keandalan } \\
\hline Cronbach's Alpha & Jumlah \\
940 & 3 \\
\hline
\end{tabular}

Tabel diatas menunjukkan nilai Cronbach's Alpha atau angka keandalan 0.940 yang mengindikasikan bahwa level keandalan yang tinggi. Skor penilai dapat dikatakan handal apabila nilai Cronbach's Alpha nya $>0.60$.

Untuk mengukur tingkat penghargaan diri siswa, dalam penelitian ini peneliti menggunakan kuisioner yang diadaptasi dari Hassan (2001) yang berjumlah 14 pernyataan. Kuisioner tersebut ditaksir dengan penilaian skala Likert yang memiliki 5 opsi pilihan, yaitu sangat setuju, setuju, kadang-kadang, tidak setuju dan sangat tidak setuju. Masing-masing opsi memiliki skor berdasarkan tabel skala Likert dibawah ini:

Table 2. Tingkatan Skala Likert

\begin{tabular}{lcc}
\hline \multirow{1}{*}{ Opsi } & \multicolumn{2}{c}{ Skor } \\
\cline { 2 - 3 } & $\begin{array}{c}\text { Pernyataan } \\
\text { Positif }\end{array}$ & Pernyataan Negatif \\
\hline Sangat Setuju & 4 & 0 \\
Setuju & 3 & 1 \\
Kadang-kadang & 2 & 2 \\
Tidak Setuju & 1 & 3 \\
Sangat tidak setuju & 0 & 4 \\
\hline
\end{tabular}

Berdasarkan hasil dari kuisioner, klasifikasi level penghargaan diri siswa dapat dilihat pada tabel berikut ini: 
Tabel 3. Klasifikasi Persentase Level Penghargaan Diri Siswa

\begin{tabular}{ccccc}
\hline No & Skor & $\begin{array}{c}\text { Jumlah } \\
\text { siswa }\end{array}$ & Persen & Deskripsi \\
\hline 1 & $38-56$ & 9 & $25 \%$ & Tinggi \\
2 & $19-37$ & 25 & $69 \%$ & Sedang/Menengah \\
3 & $0-18$ & 2 & $6 \%$ & Rendah \\
\hline Skor rata-rata: 31 & & $\mathrm{~N}=36$ & $100 \%$ & Sedang/Menengah \\
\hline & & & & (Rosenberg, 2015)
\end{tabular}

Berdasarkan tabel 3, dapat dilihat bahwa dari 36 siswa yang mengisi kuisioner, 6\% (2 siswa) dari mereka memiliki level penghargaan diri yang rendah, 69\% (25 siswa) memiliki level penghargaan diri menengah atau sedang dan 25\% (9 siswa) memiliki level penhargaan diri yang tinggi. Sedangkan nilai rata-rata dari seluruh siswa diperoleh angka sebesar 31. Oleh karena itu, dapat disimpulkan bahwa siswa kelas X MIA 2 SMAN 1 Pekanbaru berada pada level penhargaan diri yang menengah atau sedang.

Pada tes menulis dan hasil penilaian 3 orang penilai, klasifikasi kemampuan menulis siswa dapat dilihat pada tabel berikut:

Tabel 4. Persentase Level Kemampuan Menulis Siswa

\begin{tabular}{lccccc}
\hline & No & Skor & $\begin{array}{c}\text { Jumlah } \\
\text { Siswa }\end{array}$ & Persen & Deskripsi \\
\hline & 1 & $91-100$ & 2 & $5 \%$ & Baik sekali \\
& 2 & $71-90$ & 33 & $92 \%$ & Baik \\
& 3 & $31-70$ & 1 & $3 \%$ & Cukup \\
& 4 & $11-30$ & 0 & $0 \%$ & Kurang \\
& 5 & $1-10$ & 0 & $0 \%$ & Tidak diterima \\
\hline Nilai & & & & & Baik \\
Rata-rata: & 80 & $\mathrm{~N}=36$ & $100 \%$ & $($ Brown 2010) \\
\hline
\end{tabular}

(Brown, 2010)

Berdasarkan tabel diatas, dapat disimpulkan bahwa dari 36 siswa, 5\% (2 siswa) berada pada level baik sekali, 92\% (33 siswa) berada pada level baik dan 3\% (1 siswa) berada pada level cukup. Sedangkan nilai rata-rata dari seluruh siswa diperoleh nilai sebesar 80. Oleh karena itu, dapat disimpulkan bahwa kemampuan siswa kelas X MIA 2 SMAN 1 Pekanbaru dalam menulis berada pada level baik. 
Untuk menentukan hubungan antara penghargaan diri dan kemampuan menulis, peneliti menganalis data dari dua variabel tersebut menggunakan korelasi momen produk Pearson pada SPSS 20.0 yang hasilnya dapat dilihat pada tabel diberikut:

Tabel 5. Hubungan antara Penghargaan Diri dan Kemampuan Menulis

\begin{tabular}{|c|c|c|c|}
\hline \multicolumn{4}{|c|}{ Hubungan } \\
\hline & & $\begin{array}{c}\text { Pengharg-aan } \\
\text { diri }\end{array}$ & Kemampua-n menulis \\
\hline \multirow{4}{*}{ Pengha-rgaan diri } & Korelasi & 1 & $.312^{*}$ \\
\hline & Pearson & & \\
\hline & $\begin{array}{c}\text { Sig. } \\
\text { (1-arah) }\end{array}$ & & .032 \\
\hline & $\mathrm{N}$ & 36 & 36 \\
\hline \multirow{4}{*}{ Kemam-puan menulis } & Korelasi & $212^{*}$ & \\
\hline & Pearson & .512 & 1 \\
\hline & $\begin{array}{c}\text { Sig. } \\
\text { (1-arah) }\end{array}$ & .032 & \\
\hline & $\mathrm{N}$ & 36 & 36 \\
\hline & Korelasi & $\begin{array}{l}\text { pada level } 0.0 \text {. } \\
\text { l). }\end{array}$ & \\
\hline
\end{tabular}

Berdasarkan tabel diatas, dapat dilihat bahwa nilai korelasi Pearson antara penghargaan diri dan kemampuan menulis siswa yaitu 0.312 yang mana dapat dikatakan bahwa terdapat korelasi positif antara 2 variabel dan korelasi dikatakan rendah berdasarkan tabel interpretasi korelasi menurut Sudijono (2009) berikut:

Tabel 6. Interpretasi Korelasi

\begin{tabular}{cl}
\hline \multicolumn{1}{c}{$\mathrm{r}_{\mathrm{xy}}$} & \multicolumn{1}{c}{ Interpretasi } \\
\hline $0,00-0,20$ & $\begin{array}{l}\text { Terdapat korelasi yang sangat rendah diantara dua } \\
\text { variabel. }\end{array}$ \\
$0,21-0,40$ & Terdapat korelasi yang rendah diantara dua variabel. \\
$0,41-0,70$ & Terdapat korelasi yang sedang diantara dua variabel. \\
$0,71-0,90$ & Terdapat korelasi yang tinggi diantara dua dua variabel. \\
$0,91-1,00$ & Terdapat korelasi yang sangat tinggi diantara dua \\
& variabel. \\
\hline
\end{tabular}


Setelah mendapatkan nilai korelasi antara 2 variabel, untuk melihat sebesar apa keterkaitan antara 2 variabel peneliti melakukan analisis regresi sederhana me

Tabel 7. Koefisien determinasi

\begin{tabular}{|c|c|c|c|c|c|}
\hline \multicolumn{6}{|c|}{ Finglcasam Niodel } \\
\hline 콩 & $\mathbf{R}$ & 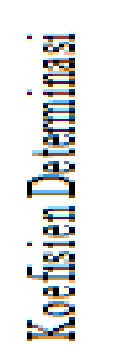 & 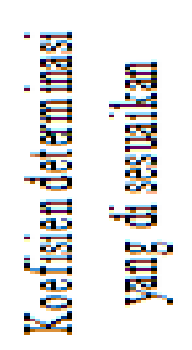 & $\begin{array}{r}\text { 意 } \\
\text { 袁 } \\
\text { 學 }\end{array}$ & 貣 \\
\hline 1 & $312=$ & 097 & 070 & 43 & 26 \\
\hline
\end{tabular}

Berdasarkan tabel diatas, dapat dilihat bahwa nilai koefisien determinasi yaitu 0.097. Jadi, dapat disimpulkan bahwa harga diri sebagai variabel independen memiliki kontribusi sebesar $9.7 \%$ terhadap kemampuan menulis, sedangkan sisanya $90.3 \%$ diperoleh dari faktor lain.

\section{SIMPULAN DAN SARAN}

\section{Simpulan}

Setelah melakukan penelitian dengan judul "hubungan antara penghargaan diri dan kemampuan menulis pada siswa tahun pertama SMAN 1 Pekanbaru”, Peneliti menemukan bahwa tingkat penghargaan diri siswa berada pada level menengah atau rata-rata yang berarti tidak terlalu tinggi dan tidak pula rendah sedangkan kemampuan menulis siswa berada pada level "baik" yang berarti kemampuan menulis mereka tidak buruk. Dari hasil analisis korelasi menggunakan korelasi momen produk Pearson pada SPSS 20.0 diperoleh nilai Korelasi Pearson yaitu 0.312 dimana diindikasikan sebagai korelasi yang rendah berdasarkan interpretasi korelasi oleh sudijono (2009) sedangkan kontribusi nya sebesar $9.7 \%$ yang berarti pada sampel penelitian ini penghargaan diri tidak banyak memengaruhi kemampuan menulis siswa. Sisanya $90.3 \%$ mungkin saja dipengaruhi oleh faktor-faktor lain yang juga menunjang pembelajaran.

\section{Saran}

Berdasarkan hasil penelitian yang menunjukkan bahwa terdapat hubungan antara penghargaan diri dan kemampuan siswa, peneliti menyarankan baik kepada siswa 
maupun guru barangkali akan lebih baik apabila siswa dan guru juga memperhatikan dan mempertimbangkan aspek kepribadian seperti harga diri dalam proses pembelajaran menulis dalam bahasa Inggris.

Peneliti juga ingin menyarankan kepada peneliti lainnya untuk tidak hanya meneliti korelasi atau hubungan antar penghargaan diri dan kemampuan menulis saja, tetapi juga aspek psikologis atau kepribadian lainnya seperti motivasi, kepercayaan diri dan juga kemampuan bahasa Inggris lainnya. Hasil dari penelitian ini barangkali bisa menjadi sumber atau referensi bagi peneliti lain yang akan melakukan penelitian serupa. Mengenang penelitian ini masih jauh dari kata sempurna, dimana sampel dalam penelitian ini hanya berjumlah 36 siswa, mungkin hasilnya akan berbeda apabila melibatkan jumlah sampel yang lebih banyak lagi. Oleh karena itu, juga disarankan bagi peneliti lain barangkali untuk melakukan penelitian yang serupa guna memahami dan memperhatikan lebih dalam lagi mengenai penghargaan diri yang hasilnya jauh lebih baik dan berguna bagi pengembangan akademis bahasa.

\section{DAFTAR PUSTAKA}

Brown, H. D. (2000). Principles of language learning \& teaching. (4th ed.). New York: Longman.

Brown, H. D. (2010). Language Assessment Principles and Classroom Practices. New York: Pearson Education.

Harmer, J. (2007). The practice of English language teaching. Harlow: Pearson Longman.

Hassan, B. A. (2001). The Relationship of Writing Apprehension and Self-Esteem to the Writing Quality and Quantity of EFL University Students.Egypt: Mansoura University.

Hisken, Loree. J. (2011). The Correlation Between Self-Esteem And Student Reading Ability, Reading Level, And Academic Achievement. Warrensburg: University of Central Missouri.

Hasan Jismulatif, Marzuki. (2017). An Analysis of Student's Ability in Writing at Riau University Pekanbaru - Indonesia. Theory and Practice in Language Studies, Vol. 7, No. 5, DOI: http://dx.doi.org/10.17507/tpls.0705.08

Jismulatif. (2016). Peningkatan Kemampuan Speaking Mahasiswa D3 STIFAR Yayasan Universitas Riau Melalui Permainan Drama, Vol. 7, No. 2. https://ejournal.unri.ac.id/index.php/JP/article/view/3861 
Jismulatif. (2018). Language Attitudes and Motivation in Learning English of Students of Physical Education of FKIP of Universitas Riau. Proceeding of the 2nd URICES, Pekanbaru, Indonesia

Kebudayaan, K. P. (2013). PeraturanMenteriPendidikandanKebudayaan No 81a tahun 2013 TentangImplementasiKurikulum 2013. Jakarta: Depdikbud.

Rosenberg, M. (2015). Society and the adolescent self-image. Princeton: Princeton University Press.

Satriani, I. (2014). Correlation Between Students'self Esteem And English Language Proficiency Of Indonesian Efl Students. Eltin Journal, Journal of English Language Teaching in Indonesia, 2(2).

Sudijono, A. (2009). Pengantar statistik pendidikan edisi I. Jakarta: Rajawali Pers. 